University of Nebraska - Lincoln

DigitalCommons@University of Nebraska - Lincoln

Agronomy \& Horticulture -- Faculty Publications

Agronomy and Horticulture Department

2012

Inheritance of grain polyphenol oxidase (PPO) activity in multiple wheat (Triticum aestivum L.) genetic backgrounds

\author{
Somrudee Nilthong \\ School of Science Mae Fah Luang University \\ Robert A. Graybosch \\ University of Nebraska-Lincoln, bob.graybosch@ars.usda.gov \\ P. Stephen Baenziger \\ University of Nebraska-Lincoln, pbaenziger1@unl.edu
}

Follow this and additional works at: https://digitalcommons.unl.edu/agronomyfacpub

Part of the Plant Sciences Commons

Nilthong, Somrudee; Graybosch, Robert A.; and Baenziger, P. Stephen, "Inheritance of grain polyphenol oxidase (PPO) activity in multiple wheat (Triticum aestivum L.) genetic backgrounds" (2012). Agronomy \& Horticulture -- Faculty Publications. 608.

https://digitalcommons.unl.edu/agronomyfacpub/608

This Article is brought to you for free and open access by the Agronomy and Horticulture Department at DigitalCommons@University of Nebraska - Lincoln. It has been accepted for inclusion in Agronomy \& Horticulture -Faculty Publications by an authorized administrator of DigitalCommons@University of Nebraska - Lincoln. 


\title{
Inheritance of grain polyphenol oxidase (PPO) activity in multiple wheat (Triticum aestivum L.) genetic backgrounds
}

\author{
Somrudee Nilthong • R. A. Graybosch • \\ P. S. Baenziger
}

Received: 22 February 2012/ Accepted: 15 July 2012

(C) Springer-Verlag (outside the USA) 2012

This article is a U.S. government work, and is not subject to copyright in the United States.

\begin{abstract}
Grain polyphenol oxidase (PPO) activity can cause discoloration of wheat (Triticum aestivum L.) food products. Five crosses (PI 117635/Antelope; Fielder/ NW03681; Fielder/Antelope; NW07OR1070/Antelope; NW07OR1066/OR2050272H) were selected to study the genetic inheritance of PPO activity. STS markers, PPO18, PPO29 and STS01, were used to identify lines with putative alleles at the Ppo-Al and Ppo-DI loci conditioning low or high PPO activity. ANOVA showed significant genotypic effects on PPO activity $(P<0.0001)$ in all populations. The generations and generation $\times$ genotype effects were not significant in any population. A putative third (null) genotype at Ppo-Al (no PCR fragments for PPO18) was discovered in NW07OR1066 and NW07OR1070 derived populations, and these had the lowest mean PPO activities. Results demonstrated that both Ppo-A1 and Ppo-D1 loci affect the kernel PPO activity, but the Ppo-Al has the major effect. In three populations, contrary results were observed to those predicted from
\end{abstract}

Née Somrudee Onto.

Communicated by P. Langridge.

S. Nilthong $\cdot$ P. S. Baenziger

Department of Agronomy and Horticulture,

University of Nebraska, Lincoln, NE 68583, USA

Present Address:

S. Nilthong

School of Science Mae Fah Luang University, 333 Moo 1,

Tambon Tasud Muang District, Chiang Rai 57100, Thailand

R. A. Graybosch $(\bowtie)$

USDA-ARS, 137 Keim, University of Nebraska, Lincoln,

NE 68583, USA

e-mail: bob.graybosch@ars.usda.gov previous work with $P p o-D 1$ alleles, suggesting the markers for Ppo-Dl allele might give erroneous results in some genetic backgrounds or lineages. Results suggest that selection for low or null alleles only at Ppo-Al might allow development of low PPO wheat cultivars.

\section{Introduction}

Polyphenol oxidase (PPO, E.C. 1.14.18.1 is present in most plant species (Robb 1984; Flurkey 1989; Steffens et al. 1994; Lee and Whitaker 1995). PPO catalyzes the formation of quinones which in turn react with amines and thiol groups or undergo self-polymerization to produce dark gray or brown products (Mayer and Harel 1979). In food products derived from common wheat (Triticum aestivum L.), PPO is a major contributor to time-dependent discoloration (Baik et al. 1995; Kruger et al. 1994; Feillet et al. 2000; Singh and Sheoran 1972). Levels of PPO activity in wheat grain vary among different cultivars and breeding lines, and PPO activity is also influenced by environment (Baik et al. 1994; Park et al. 1997). PPO activity can be measured on flour or whole seed using either oxygen consumed (Marsh and Galliard 1986) or the production of colored products (spectrophotometric method). Enzyme substrates have included phenol (Wrigley 1976), catechol (Milner and Gould 1951), L-tyrosine (Bernier and Howes 1994; McCaig et al. 1999) and L-3,4-dihydroxyphenyl alanine (L-DOPA) (Anderson and Morris 2001). Whole seed assays can rapidly characterize wheat germplasm for PPO variation (Anderson and Morris 2001; Raman et al. 2005).

Previous studies in wheat have shown that major genes controlling PPO activity are located on wheat homeologous group 2 chromosomes (Udall 1996; Jimenez and 
Dubcovsky 1999; Anderson and Morris 2001; Demeke et al. 2001; Mares and Campbell 2001), but activity might be modulated or influenced by additional genes on group 3 (Udall 1996; Demeke et al. 2001), group 5 (Udall 1996), 6B and 7D chromosomes ( $\mathrm{Li}$ et al. 1999). Raman et al. (2005) identified a major locus controlling PPO activities on the long arm $(2 \mathrm{AL})$ of chromosome $2 \mathrm{~A}$ in a doubledhaploid population derived from Chara/WW2449, explaining $82-84 \%$ of the genetic variation, using a QTL mapping approach.

Demeke and Morris (2002) cloned the first partial sequence of a wheat PPO gene (Genbank Accession Number AF507945) using a pair of primers designed from conserved copper-binding regions of other plant PPO genes. Subsequently, Jukanti et al. (2004) cloned several additional partial sequences of wheat PPO genes by assembling expressed sequence tags (ESTs). Sun et al. (2005) developed STS marker PPO18 derived from a PPO gene (Genbank Accession Number AY596268) located on chromosome arm 2AL and found it to be an efficient molecular marker for wheat kernel PPO activity. PPO18 amplified a 685-bp fragment in genotypes with high PPO activity (Ppo-Ala allele) and an 876-bp fragment in lines with low PPO activity (Ppo-Alb). He et al. (2007) characterized a complete genomic DNA sequence of two PPO genes designated Ppo-Al and Ppo-Dl, located on chromosome $2 \mathrm{~A}$ and $2 \mathrm{D}$, respectively, and developed two complementary dominant STS markers, PPO16 and PPO29 for the Ppo-D1 gene. PPO16 amplified a 713-bp (Ppo-D1a) fragment in cultivars with low PPO activity and PPO29 amplified a 490-bp (Ppo-D1b) fragment in cultivars with high PPO activity. Based on a wheat grain PPO mRNA sequence (Genbank Accession Number AY15506), an STS marker (STS01) was developed which could effectively discriminate two alleles of the Ppo-Dl gene (Wang et al. 2008). Comparison of STS01 with the STS marker PPO29 showed that STS01 was the complementary maker of PPO29 and a surrogate for PPO16. STS01 amplified a 560-bp PCR fragment in cultivars with mostly low PPO activity (Wang et al. 2008). Previous studies generally have been restricted to cultivar surveys, and the evaluation of populations segregating for high and low PPO conditioning alleles has not been reported.

The use of molecular markers associated with PPO activity has the potential to improve selection efficiency for lines with low activity. In prior work (Onto 2011) with lines derived from the mating of two low PPO wheats PI 117635 and IDO377s, markers PPO29 and STS01 showed opposite results from those predicted at the Ppo-Dl locus. To determine whether this observation was common to additional wheat lineages, we developed five new populations (1) to further examine inheritance of PPO activity in multiple wheat genetic backgrounds and (2) to further evaluate the relationship between PPO activity and alleles at the two major common wheat PPO-encoding loci.

\section{Materials and methods}

Plant materials

Twenty-seven white-seeded wheat genotypes (Table 1) derived from either Australia or the USA were checked with DNA markers. Subsequently, selected lines were used as parents to develop five breeding populations. Pedigrees of evaluated populations were: PI 117635/'Antelope'; 'Fielder'/ NW03681; Fielder/Antelope; NW07OR1070/Antelope; NW07OR1066/OR2050272H. PI 117635 was developed in Australia and added to the USDA National Small Grains Collection in 1936. Fielder (CItr 17268) is a soft white spring wheat developed in Idaho, USA, released in 1975. Antelope is a hard white winter wheat developed by USDA-ARS, University of Nebraska, USA, released in 2002. NW07OR1066 and NW07OR1070 are two white spring wheat breeding lines developed by USDA-ARS, University of Nebraska, both derived from the mating PI117635/'Seaspray'. Seaspray (PI 134049) was released as a cultivar in Australia in 1934. OR2050272H is a hard white winter wheat breeding line developed by Oregon State University, USA. NW03681 is an experimental hard white winter wheat breeding line developed by the University of Nebraska. Initial crosses were produced in a greenhouse in spring 2009 at the University of Nebraska. All $F_{1}$ seeds of each cross were planted in the greenhouse in fall 2009. The heads of each $F_{1}$ plant were harvested and threshed as $F_{2}$ seeds. A total of $144 F_{2}$ seeds were randomly planted per population in the greenhouse in spring 2010 and used to evaluate the correlation between PPO levels and PPO alleles at the Ppo-Al and Ppo-DI loci. One seed per $\mathrm{F}_{2}$ head was randomly planted to obtain $\mathrm{F}_{3}$ generations. Each plant was harvested and threshed as $\mathrm{F}_{3: 4}$ seeds, and PPO activity was again evaluated. All generations were greenhouse grown, as populations derived from straight winter/spring wheat crosses will not survive northern Great Plains winter conditions. All parents were planted in single pots, three replication each, along with each generation. Plants were genotyped at $F_{1}, F_{2}$ and $F_{3}$ generations. For convenience, genotypes were designated as follows:

$$
\begin{aligned}
& \mathrm{AA}=\text { Ppo-Ala/Ppo-Dlb } \mathrm{AH}=\text { Ppo-Ala/Ppo-Dla/b } \\
& \mathrm{AB}=\text { Ppo-Ala/Ppo-Dla } \\
& \mathrm{HA}=\text { Ppo-Alab/Ppo-Dlb } \mathrm{HH}=\text { Ppo-Alab/Ppo-Dla/b } \\
& \mathrm{HB}=\text { Ppo-Alab/Ppo-Dla } \\
& \mathrm{BA}=\text { Ppo-Alb/Ppo-Dlb } \mathrm{BH}=\text { Ppo-Alb/Ppo-Dla/b } \\
& \mathrm{BB}=\text { Ppo-Alb/Ppo-Dla } \\
& \mathrm{NA}=\text { null allele/Ppo-Dlb } \mathrm{NH}=\text { null allele/Ppo-Dla/b } \\
& \mathrm{NB}=\text { null allele/Ppo-Dla } .
\end{aligned}
$$


Table 1 DNA marker results from a preliminary assessment of white wheat germplasm

\begin{tabular}{|c|c|c|c|c|c|c|c|c|c|}
\hline \multirow[t]{3}{*}{ Cultivars } & \multicolumn{2}{|l|}{$2 \mathrm{~A}$} & \multicolumn{2}{|l|}{$2 \mathrm{D}$} & \multirow[t]{3}{*}{ Cultivars } & \multicolumn{2}{|l|}{$2 \mathrm{~A}$} & \multicolumn{2}{|l|}{$2 \mathrm{D}$} \\
\hline & PPO18 & PPO18 & PPO29 & STS01 & & PPO18 & PPO18 & PPO29 & STS01 \\
\hline & 685-bp & 876-bp & 490-bp & $560-$ bp & & 685-bp & 876-bp & 490-bp & 560-bp \\
\hline Antelope & + & - & - & + & OR2060092H & + & - & - & + \\
\hline Anton & - & + & - & + & OR2060099H & + & - & - & + \\
\hline Arrowsmith & + & - & + & - & OR2060101H & + & - & - & + \\
\hline Cook & + & - & - & + & OR2060108H & - & + & - & + \\
\hline Fielder & - & + & + & - & PI 117635 & - & + & + & - \\
\hline HV9W02-267W & + & - & + & - & Tincurrin & - & + & - & + \\
\hline IDO377s & - & + & - & + & NW07OR1040 & - & - & + & - \\
\hline IDO580 & - & + & - & + & NW07OR1062 & - & - & + & - \\
\hline NW03681 & + & - & - & + & NW07OR1066 & - & - & + & - \\
\hline OR2050042H & - & + & - & + & NW07OR1070 & - & - & + & - \\
\hline OR2050186H & + & - & + & - & NW07OR1071 & - & - & + & - \\
\hline OR2050272H & - & + & - & + & NW07OR1073 & - & - & + & - \\
\hline OR2060051H & - & + & - & + & NW07OR1074 & - & - & + & - \\
\hline OR2060074H & + & - & - & + & & & & & \\
\hline
\end{tabular}

The null allele is a putative new allele at Ppo-Al. Putative alleles conditioning high grain PPO, designated "A" herein, based on Sun et al. (2005), He et al. (2007) and Wang et al. (2008) are Ppo-Ala and Ppo-Dlb; Ppo-Alb and $P$ po-Dla (designated "B") are putative alleles conditioning low PPO.

\section{Measurement of PPO activity}

Polyphenol oxidase activity in whole wheat grains was determined for all parents and progeny lines in the $F_{2}$ and $\mathrm{F}_{3}$ generations using the L-DOPA (3, 4-dihydroxyphenylalanine, Sigma-Aldrich Co., St. Louis, MO) assay reported by Anderson and Morris (2001). Seeds from the cultivars 'Arapahoe' (red winter wheat with high PPO activity), 'Anton' (white winter wheat with low to moderate PPO activity), and 'Ben' [spring durum (Triticum turgidum L.) wheat with low PPO activity] were included as experimental controls to check the consistency of each run. Each reaction was repeated two times. The L-DOPA solution was made fresh daily.

\section{DNA isolation and STS analysis}

PCR-based molecular markers, PPO18, PPO29, and STS01, were used to identify lines carrying alleles possibly conditioning low or high PPO levels. Genomic DNA was extracted from young leaf tissues using a CTAB (cetyltrimethyl ammonium bromide) method (Doyle and Doyle 1987). Sequence tagged site (STS) markers PPO18, PPO29, and STS01 were synthesized by Invitrogen Co. (Carlsbad, CA) using primers presented in He et al. (2007) and Wang et al. (2008). PCR reactions were performed in a total volume of $25 \mu \mathrm{l}$ containing $100 \mathrm{ng}$ of genomic DNA, $10 \mathrm{mM}$ Tris$\mathrm{HCl}, 1.5 \mathrm{mM} \mathrm{MgCl}_{2}, 50 \mathrm{mM} \mathrm{KCl}$ buffer, $0.2 \mathrm{mM}$ of each $\mathrm{dNTP}, 0.4 \mu \mathrm{M}$ of each oligonucleotide primer, and 0.028 unit of Taq DNA polymerase (Roach, Mannheim, Germany) in a Bio-Rad DNA Engine Peltier Thermal Cycler. The thermocycling program was $95{ }^{\circ} \mathrm{C}$ for $5 \mathrm{~min}$, followed by 40 cycles of touchdown PCR at $95{ }^{\circ} \mathrm{C}$ for $1 \mathrm{~min}, 56-50{ }^{\circ} \mathrm{C}$ for 1:30 min for PPO18 or $62-57{ }^{\circ} \mathrm{C}$ for $1 \mathrm{~min}$ for STS01, $72{ }^{\circ} \mathrm{C}$ for $2 \mathrm{~min}$, with a final extension of $72{ }^{\circ} \mathrm{C}$ for $8 \mathrm{~min}$. PPO29 PCR amplification was performed at $95{ }^{\circ} \mathrm{C}$ for $5 \mathrm{~min}$, followed by 36 cycles of $94{ }^{\circ} \mathrm{C}$ for $1 \mathrm{~min}, 69.6{ }^{\circ} \mathrm{C}$ for $1 \mathrm{~min}$, and $72{ }^{\circ} \mathrm{C}$ for $1 \mathrm{~min}$, with final extension of $72{ }^{\circ} \mathrm{C}$ for $8 \mathrm{~min}$. Amplified PCR fragments were separated on $1.5 \%$ agarose gels and stained with ethidium bromide and visualized using UV light.

\section{Statistical analysis}

All statistical computations were made using the SAS computer packages version 9.2 for Windows (SAS Institute Inc., Cary, NC, USA). Analysis of variance (ANOVA) was used to test for significant differences among generation, genotype, and generation $\times$ genotype using PROC GLM. Chi-square tests were used to analyze the genotypic ratio of marker segregation using PROC FREQ. Both raw and square-root transformed data were analyzed, but as no difference in the two approaches was detected, only raw data will be discussed. PROC MIXED was used to test population means against each other. 
Table 2 Chi-square analysis of observed $\mathrm{F}_{2}$ segregation ratios of alleles at Ppo-A1 and Ppo-D1, as determined by DNA markers

\begin{tabular}{|c|c|c|c|c|}
\hline Source & $n$ & Observed ratio & $\chi^{2}$ test & $\operatorname{Pr}>F$ \\
\hline \multicolumn{5}{|l|}{ Parent: PI117635/Antelope } \\
\hline $2 \mathrm{~A}: 1 \mathrm{~A}: 2 \mathrm{H}: 1 \mathrm{~B}^{\mathrm{a}}$ & 135 & 29: $72: 34$ & 0.9704 & 0.6156 \\
\hline 2D: $1 \mathrm{~A}: 2 \mathrm{H}: 1 \mathrm{~B}$ & & $38: 55: 42$ & 4.8667 & 0.0877 \\
\hline 2A2D: 1AA: 2AH: 1AB: 2HA: 4HH: 2HB: 1BA: 2BH: 1BB & & 7: 13: 9: 23: 25: 24: 8: 17: 9 & 8.7333 & 0.3653 \\
\hline \multicolumn{5}{|l|}{ Parent: Fielder/NW03681 } \\
\hline 2A: $1 \mathrm{~A}: 2 \mathrm{H}: 1 \mathrm{~B}$ & 114 & 29: 60: 25 & 0.5965 & 0.7421 \\
\hline 2D: $1 \mathrm{~A}: 2 \mathrm{H}: 1 \mathrm{~B}$ & & 29: $49: 36$ & 3.1053 & 0.2117 \\
\hline 2A2D: 1AA: 2AH: 1AB: 2HA: 4HH: 2HB: 1BA: 2BH: 1BB & & 9: $12: 8: 12: 35: 15: 8: 4: 13$ & 14.3860 & 0.0722 \\
\hline \multicolumn{5}{|l|}{ Parent: Fielder/Antelope } \\
\hline 2A: $1 \mathrm{~A}: 2 \mathrm{H}: 1 \mathrm{~B}$ & 136 & 40: 76: 20 & 7.7647 & $0.0206 *$ \\
\hline 2D: $1 \mathrm{~A}: 2 \mathrm{H}: 1 \mathrm{~B}$ & & 43: $56: 37$ & 4.7647 & 0.0923 \\
\hline 2A2D: 1AA: 2AH: 1AB: 2HA: 4HH: 2HB: 1BA: 2BH: 1BB & & 12: 16: 12: 28: $31: 17: 3: 9: 8$ & 17.6765 & $0.0238^{*}$ \\
\hline \multicolumn{5}{|l|}{ Parent: NW07OR1070/Antelope } \\
\hline $2 \mathrm{~A}: 3 \mathrm{~A}: 1 \mathrm{~N}$ & 116 & 81: 35 & 1.6552 & 0.1983 \\
\hline 2D: $1 \mathrm{~A}: 2 \mathrm{H}: 1 \mathrm{~B}$ & & 32: $54: 30$ & 0.6207 & 0.7332 \\
\hline 2A2D: 3AA: 1NA: 6AH: 2NH: 3AB: 1NB & & 19: 13: 40: 14: $22: 8$ & 5.2874 & 0.3818 \\
\hline \multicolumn{5}{|l|}{ Parent: NW07OR1066/OR2050272H } \\
\hline $2 \mathrm{~A}: 3 \mathrm{~B}: 1 \mathrm{~N}$ & 139 & 91: 48 & 6.7362 & $0.0094 *$ \\
\hline 2D: $1 \mathrm{~A}: 2 \mathrm{H}: 1 \mathrm{~B}$ & & 36: $62: 41$ & 1.9784 & 0.3719 \\
\hline 2A2D: 3BA: 1NA: 6BH: 2NH: 3BB: 1NB & & 21: $14: 38: 24: 32: 10$ & 12.1367 & $0.0330^{*}$ \\
\hline
\end{tabular}

* Significantly different at $P=0.05$

${ }^{\mathrm{a}} \mathrm{AA}=$ Ppo-A1a/Ppo-D1b $\mathrm{AH}=$ Ppo-A1a/Ppo-D1a/b AB = Ppo-A1a/Ppo-D1a HA = Ppo-A1ab/Ppo-D1b HH = Ppo-A1ab/Ppo-D1a/b $\mathrm{HB}=$ Ppo-A1ab/Ppo-D1a $\quad$ BA $=$ Ppo-A1b/Ppo-D1b $\quad$ BH $=$ Ppo-A1b/Ppo-D1a/b $\quad$ BB = Ppo-A1b/Ppo-D1a NA = null allele/Ppo-D1b $\mathrm{NH}=$ null allele/Ppo-D1a/b NB $=$ null allele/Ppo-D1a

\section{Results}

Inheritance of DNA markers

The 27 cultivars were checked with markers and the results are shown in Table 1. However, in these materials, a putative third (null) genotype (no PCR fragments for PPO18) was discovered in NW07OR1040, NW07OR1062, NW07OR1066, NW07OR1070, NW07OR1071, NW07O R1073, and NW07OR1074. All these lines were derived from the same cross (PI 117635/Sea Spray). $F_{1}$ seed from five crosses were planted in the greenhouse in the autumn of 2009, and STS markers confirmed the hybrid nature of each $\mathrm{F}_{1}$ plant. PPO18 produced 685-bp (A pattern) and 876-bp (B pattern) PCR fragments, identifying Ppo-Ala and $P$ po- $A 1 b$, respectively (Sun et al. 2005). Complementary STS marker PPO29 and STS01 amplified a 490-bp product (A pattern), indicating Ppo-Dlb and a 560-bp fragment (B pattern), indicating Ppo-Dla, respectively (He et al. 2007; Wang et al. 2008). The $\mathrm{F}_{1}$ genotypes of all five crosses consisted of both $P p o-A 1$ and $P p o-D 1$ alleles from the parents. However, of the five crosses, two crosses, derived from either NW07OR1070 and NW07OR1066 parents, contained lines with no PCR fragments from PPO18 and were designated the null genotype ( $\mathrm{N}$ pattern).

Expected $\mathrm{F}_{2}$ and $\mathrm{F}_{3}$ genotypes, and segregation ratios, are presented for all five populations in Tables 2 and 3, respectively. The presence of the null allele at Ppo-AI in the NW07OR1070/Antelope and NW07OR1066/ OR2050272H populations prevented recognition of heterozygous $(\mathrm{H})$ genotypes at this locus in these two populations. Hence, expected genotypes and ratios differed in these two populations, when compared with the remaining three populations in which markers allowed designation of heterozygotes at both loci in both generations. With few exceptions, observed $\mathrm{F}_{2}$ and $\mathrm{F}_{3}$ genotypic ratios did not deviate from the expected, based on $\chi^{2}$ analysis (Tables 2,3 ). The only exceptions were the population derived from Fielder/Antelope, in which a deficiency of the B genotype was observed at Ppo-A1 in both $F_{2}$ and $F_{3}$ generations, and NW07OR1066/ OR2050272H, which displayed significant departures from expected ratios in the $F_{2}$, but not the $F_{3}$ generation. 
Table 3 Chi-square analysis of observed $\mathrm{F}_{3}$ segregation ratios of alleles at Ppo-A1 and Ppo-D1, as determined by DNA markers

\begin{tabular}{|c|c|c|c|c|}
\hline Source & $n$ & Observed ratio & $\chi^{2}$ test & $\operatorname{Pr}>F$ \\
\hline \multicolumn{5}{|l|}{ Parent: PI117635/Antelope } \\
\hline $2 \mathrm{~A}: 3 \mathrm{~A}: 2 \mathrm{H}: 3 \mathrm{~B}^{\mathrm{a}}$ & \multirow[t]{3}{*}{125} & 44: $33: 48$ & 0.3013 & $0.8601 \mathrm{NS}$ \\
\hline 2D: $3 \mathrm{~A}: 2 \mathrm{H}: 3 \mathrm{~B}$ & & 48: $35: 42$ & 0.9840 & $0.6114 \mathrm{NS}$ \\
\hline 2A2D: 9AA: 6AH: 9AB: 6HA: 4HH: 6HB: 9BA: 6BH: 9BB & & 19: 10: 14: 16: 6: 11: 13: 18: 17 & 7.4942 & $0.4844 \mathrm{NS}$ \\
\hline \multicolumn{5}{|l|}{ Parent: Fielder/NW03681 } \\
\hline 2A: $3 \mathrm{~A}: 2 \mathrm{H}: 3 \mathrm{~B}$ & \multirow[t]{3}{*}{106} & 41: $30: 35$ & 1.0692 & $0.5859 \mathrm{NS}$ \\
\hline 2D: $3 \mathrm{~A}: 2 \mathrm{H}: 3 \mathrm{~B}$ & & 35: $29: 42$ & 0.9308 & $0.6279 \mathrm{NS}$ \\
\hline 2A2D: 9AA: 6AH: 9AB: 6HA: 4HH: 6HB: 9BA: 6BH: 9BB & & 18: 10: 13: 5: 11: 14: 12: $8: 15$ & 8.8344 & $0.3565 \mathrm{NS}$ \\
\hline \multicolumn{5}{|l|}{ Parent: Fielder/Antelope } \\
\hline $2 \mathrm{~A}: 3 \mathrm{~A}: 2 \mathrm{H}: 3 \mathrm{~B}$ & \multirow[t]{3}{*}{139} & 63: $39: 37$ & 7.1775 & $0.0276^{*}$ \\
\hline 2D: $3 \mathrm{~A}: 2 \mathrm{H}: 3 \mathrm{~B}$ & & 51: 29: 59 & 1.8825 & $0.3901 \mathrm{NS}$ \\
\hline 2A2D: 9AA: 6AH: 9AB: 6HA: 4HH: 6HB: 9BA: 6BH: 9BB & & 20: 11: 32: 20: 5: 14: 11: 13: 13 & 19.5548 & $0.0122 *$ \\
\hline \multicolumn{5}{|l|}{ Parent: NW07OR1070/Antelope } \\
\hline $2 \mathrm{~A}: 5 \mathrm{~A}: 3 \mathrm{~N}$ & \multirow[t]{3}{*}{114} & 66: 48 & 1.0316 & $0.3098 \mathrm{NS}$ \\
\hline 2D: $3 \mathrm{~A}: 2 \mathrm{H}: 3 \mathrm{~B}$ & & 38: $39: 37$ & 5.1696 & $0.0754 \mathrm{NS}$ \\
\hline 2A2D: 15AA: 9NA: 10AH: 6NH: 15AB: 9NB & & 17: 21: 27: 12: $22: 15$ & 10.8405 & $0.0546 \mathrm{NS}$ \\
\hline \multicolumn{5}{|l|}{ Parent: NW07OR1066/OR2050272H } \\
\hline $2 \mathrm{~A}: 5 \mathrm{~B}: 3 \mathrm{~N}$ & \multirow[t]{3}{*}{135} & $85: 50$ & 0.0123 & $0.9115 \mathrm{NS}$ \\
\hline 2D: $3 \mathrm{~A}: 2 \mathrm{H}: 3 \mathrm{~B}$ & & 43: 40: 52 & 2.3432 & $0.3099 \mathrm{NS}$ \\
\hline 2A2D: 15BA: 9NA: 10BH: 6NH: 15BB: 9NB & & 20: $23: 28: 12: 37: 15$ & 9.1845 & $0.1019 \mathrm{NS}$ \\
\hline
\end{tabular}

* Significantly different at $P=0.05$

${ }^{\mathrm{a}} \mathrm{AA}=$ Ppo-A1a/Ppo-D1b $\mathrm{AH}=$ Ppo-A1a/Ppo-D1a/b $\quad$ AB = Ppo-A1a/Ppo-D1a $\quad$ HA = Ppo-A1ab/Ppo-D1b HH = Ppo-A1ab/Ppo-D1a/b $\mathrm{HB}=$ Ppo-A1ab/Ppo-D1a $\quad$ BA $=$ Ppo-A1b/Ppo-D1b $\quad$ BH $=$ Ppo-A1b/Ppo-D1a $/ b \quad$ BB $=$ Ppo-A1b/Ppo-D1a NA = null allele/Ppo-D1b $\mathrm{NH}=$ null allele/Ppo-D1a/b NB $=$ null allele/Ppo-D1a

PPO activity

ANOVA, calculated separately for each population, revealed no significant effect on PPO activities of generation or generation $\times$ genotype in any of the five populations (Table 4). Significant differences due to genotype alone, however, were detected in all five populations, demonstrating that much of the observed variation in PPO activity in these materials is governed by these two major loci.

The relationship between specific genotypes and PPO activities is presented for the $F_{2}$ and $F_{3}$ generations in Tables 5 and 6, respectively, along with PPO activities of all parents, grown in the same greenhouse environments with each generation. Observed ranges in PPO activity of progeny lines are displayed in Figs. 1 and 2. As results differed by population, each will be discussed in turn.

\section{PI 117635/Antelope}

PI 117635 had significantly lower mean PPO activity than Antelope when grown with both generations. Mean PPO activity of PI 117635 and Antelope were $0.073 \pm 0.002$ and $0.606 \pm 0.042 \mathrm{AU}$ when grown with the $\mathrm{F}_{2}$ generation, and $0.126 \pm 0.008$ and $0.466 \pm 0.157 \mathrm{AU}$ when grown with the $\mathrm{F}_{3}$ generation, respectively. In both generations, individual lines with PPO activities equal to the low PPO parent, PI 117635, were observed (Fig. 1). The population means were $0.388 \pm 0.016 \mathrm{AU}$ in the $\mathrm{F}_{2}$ generation and $0.368 \pm 0.021 \mathrm{AU}$ in the $\mathrm{F}_{3}$ generation. For both generations, genotypes $\mathrm{AA}, \mathrm{AH}$, and $\mathrm{AB}$ with the putative high PPO allele at Ppo-Al demonstrated the highest PPO activity. In the $\mathrm{F}_{2}$ generation, activities of genotypes BA (putative high Ppo-A1, low Ppo-D1 alleles) and BB (two putative low alleles) did not differ. In the $\mathrm{F}_{3}$, PPO activities of $\mathrm{BB}$ significantly exceeded those of $\mathrm{BA}$, in contrast to the results expected from previous reports.

\section{Fielder/NW03681}

The average PPO activity of Fielder was $0.584 \pm 0.012$ $\mathrm{AU}$ when grown with the $\mathrm{F}_{2}$ generation and $0.464 \pm 0.098$ $\mathrm{AU}$ when grown with the $\mathrm{F}_{3}$ generation, while NW03681 displayed mean PPO activities of $0.726 \pm 0.000 \mathrm{AU}$ when grown with the $\mathrm{F}_{2}$ generation and $0.361 \pm 0.015 \mathrm{AU}$ with the $\mathrm{F}_{3}$ generation. The minimum and maximum $\mathrm{PPO}$ 
Table 4 Mean squares from analysis of variance of PPO activity from five breeding populations grown for two generations under greenhouse conditions

\begin{tabular}{|c|c|c|c|}
\hline Source of variance & $d f$ & Mean square & $\operatorname{Pr}>F$ \\
\hline \multicolumn{4}{|l|}{ Pop 1: PI 117635/Antelope } \\
\hline Generation & 1 & 0.0003 & 0.9051 \\
\hline Genotype & 8 & 0.7564 & $<0.0001^{*}$ \\
\hline Generation $\times$ genotype & 8 & 0.0170 & 0.5014 \\
\hline Error & 235 & 0.0185 & \\
\hline \multicolumn{4}{|l|}{ Pop 2: Fielder/NW03681 } \\
\hline Generation & 1 & 1.5787 & $<0.0001^{*}$ \\
\hline Genotype & 8 & 0.4248 & $<0.0001^{*}$ \\
\hline Generation $\times$ genotype & 8 & 0.0807 & 0.1974 \\
\hline Error & 200 & 0.0575 & \\
\hline \multicolumn{4}{|l|}{ Pop 3: Fielder/Antelope } \\
\hline Generation & 1 & 0.4036 & 0.0126 \\
\hline Genotype & 8 & 0.5190 & $<0.0001^{*}$ \\
\hline Generation $\times$ genotype & 8 & 0.0742 & 0.3234 \\
\hline Error & 250 & 0.0639 & \\
\hline \multicolumn{4}{|c|}{ Pop 4: NW07OR1070/Antelope } \\
\hline Generation & 1 & 0.0005 & 0.9109 \\
\hline Genotype & 5 & 0.7978 & $<0.0001^{*}$ \\
\hline Generation $\times$ genotype & 5 & 0.0481 & 0.2642 \\
\hline Error & 212 & 0.0369 & \\
\hline \multicolumn{4}{|c|}{ Pop 5: NW07OR1066/OR2050272H } \\
\hline Generation & 1 & 0.0067 & 0.2064 \\
\hline Genotype & 5 & 0.1010 & $<0.0001^{*}$ \\
\hline Generation $\times$ genotype & 5 & 0.0025 & 0.7015 \\
\hline Error & 231 & 0.0042 & \\
\hline
\end{tabular}

* Significantly different at $P=0.05$

activities for the lines in the $\mathrm{F}_{2}$ generation were 0.085 and $1.113 \mathrm{AU}$, and 0.090 and $1.438 \mathrm{AU}$ for the lines in the $\mathrm{F}_{3}$ generation, (Fig. 1), with many lines both significantly lower than both parents, and in the range of low PPO line PI 117635, demonstrating that low PPO lines can arise from parents with medium to high PPO levels. Genotypes in this population behaved as expected, with $\mathrm{PPO}$ activities of $\mathrm{AA}>\mathrm{AB}=\mathrm{BA}>\mathrm{BB}$ in both generations.

\section{Fielder/Antelope}

The parents Fielder and Antelope had similar PPO activities when grown with both $F_{2}$ and $F_{3}$ generations: $0.584 \pm 0.012$ and $0.606 \pm 0.042 \mathrm{AU}$ when grown with the $F_{2}$ generation and $0.464 \pm 0.098$ and $0.466 \pm 0.157$ AU when grown with the $F_{3}$ generation, respectively. The PPO activity for the lines in the $\mathrm{F}_{2}$ generation ranged from 0.136 to $0.945 \mathrm{AU}$ and from 0.085 to $1.793 \mathrm{AU}$ for the lines in the $\mathrm{F}_{3}$ generation (Fig. 1). These results demonstrate that both low and high PPO lines can be derived from matings of cultivars with high PPO activities. In both the $\mathrm{F}_{2}$ and $\mathrm{F}_{3}$ generations, the BB genotype had the lowest PPO activity and the AA genotype had the highest PPO activity, with BA and AB displaying intermediate phenotypes. These observations again agreed with the expectation based on previous marker work.

\section{NW07OR1070/Antelope}

NW07OR1070 displayed a significantly lower average PPO activity than Antelope (Tables 5, 6; Fig. 2). The PPO activity for the population ranged from 0.024 to $0.745 \mathrm{AU}$ for the lines in the $\mathrm{F}_{2}$ generation and 0.031-1.431 AU for the lines in the $\mathrm{F}_{3}$ population. The mean PPO activities were $0.355 \pm 0.016 \mathrm{AU}$ for the lines in the $\mathrm{F}_{2}$ generation and $0.342 \pm 0.027 \mathrm{AU}$ for the lines in the $\mathrm{F}_{3}$ generation, a lower population mean PPO activity than PI 117635/Antelope, Fielder/NW03681, and Fielder/Antelope populations. The putative null allele at Ppo-Al contributed to significantly lower activities in both generations, with the NA and NB classes displaying significantly lower PPO activities than the AA and AB classes. PPO activity of NA and NB classes was not significantly different; likewise, activity of $\mathrm{AA}$ and $\mathrm{AB}$ classes also was not significantly different. The results of this population suggest that PpoAl exerts greater control of PPO activity, and that the putative null allele at this locus markedly reduces PPO activity.

\section{NW07OR1066/OR2050272H}

The average PPO activity for NW07OR1066 was $0.068 \pm 0.035 \mathrm{AU}$ when grown with the $\mathrm{F}_{2}$ generation and $0.079 \pm 0.022 \mathrm{AU}$ when grown with the $\mathrm{F}_{3}$ generation. Mean PPO activities of OR2050272H were $0.262 \pm 0.017$ AU when grown with the $F_{2}$ generation and $0.299 \pm 0.139$ AU when grown with the $\mathrm{F}_{3}$ generation. The minimum and maximum PPO activities for NW07OR1066/OR2050272H population were 0.035 and $0.465 \mathrm{AU}$ for the $\mathrm{F}_{2}$ generation and 0.024 and $0.466 \mathrm{AU}$ for the $\mathrm{F}_{3}$ generation (Fig. 2). The overall mean PPO activity was $0.154 \pm 0.006$ AU for the lines in the $\mathrm{F}_{2}$ generation and $0.148 \pm 0.0 .009 \mathrm{AU}$ for the lines in the $\mathrm{F}_{3}$ generation, giving this population the lowest mean PPO activity of all five populations. The mean PPO activity of each genotype is shown in Tables 5 and 6 . In both the $F_{2}$ and $F_{3}$ generations, the NB genotype was expected to have the lowest PPO activity as in the NW07OR1070/Antelope population and the BA genotype was expected to have the highest PPO activity. However, the observations showed the NA genotype had the lowest PPO activity and the BB genotype had the highest PPO activity in both generations. 
Table 5 Genotypes and PPO activity of all $\mathrm{F}_{2}$ populations and parents

\begin{tabular}{|c|c|c|c|c|c|c|c|c|c|}
\hline \multicolumn{2}{|l|}{$2 \mathrm{~A}$} & \multicolumn{2}{|l|}{$2 \mathrm{D}$} & \multirow[t]{2}{*}{ Genotypes $^{\mathrm{a}}$} & \multicolumn{5}{|c|}{ PPO activity (mean \pm SD) } \\
\hline $\begin{array}{l}\text { PPO18 } \\
685-b p\end{array}$ & $\begin{array}{l}\text { PPO18 } \\
\text { 876-bp }\end{array}$ & $\begin{array}{l}\text { PPO29 } \\
490-b p\end{array}$ & $\begin{array}{l}\text { STS01 } \\
560-\text {-bp }\end{array}$ & & $\begin{array}{l}\text { Population } 1 \\
\text { PI 117635/Antelope }\end{array}$ & $\begin{array}{l}\text { Population } 2 \\
\text { Fielder/NW03681 }\end{array}$ & $\begin{array}{l}\text { Population } 3 \\
\text { Fielder/Antelope }\end{array}$ & $\begin{array}{l}\text { Population } 4 \\
\text { NW07OR1070/ } \\
\text { Antelope }\end{array}$ & $\begin{array}{l}\text { Population } 5 \\
\text { NW07OR1066/ } \\
\text { OR2050272H }\end{array}$ \\
\hline+ & - & + & - & AA & $0.52 \pm 0.08$ & $0.53 \pm 0.05$ & $0.64 \pm 0.05$ & $0.41 \pm 0.03$ & - \\
\hline+ & - & + & + & $\mathrm{AH}$ & $0.60 \pm 0.04$ & $0.63 \pm 0.08$ & $0.62 \pm 0.06$ & $0.41 \pm 0.02$ & - \\
\hline+ & - & - & + & $\mathrm{AB}$ & $0.57 \pm 0.06$ & $0.35 \pm 0.07$ & $0.60 \pm 0.06$ & $0.44 \pm 0.02$ & - \\
\hline- & + & + & - & BA & $0.14 \pm 0.02$ & $0.31 \pm 0.07$ & $0.36 \pm 0.22$ & - & $0.11 \pm 0.02$ \\
\hline- & + & + & + & $\mathrm{BH}$ & $0.19 \pm 0.01$ & $0.18 \pm 0.04$ & $0.43 \pm 0.03$ & - & $0.16 \pm 0.01$ \\
\hline- & + & + & - & $\mathrm{BB}$ & $0.16 \pm 0.03$ & $0.23 \pm 0.03$ & $0.28 \pm 0.01$ & - & $0.20 \pm 0.01$ \\
\hline+ & + & + & - & HA & $0.39 \pm 0.02$ & $0.42 \pm 0.04$ & $0.55 \pm 0.03$ & - & - \\
\hline+ & + & + & + & $\mathrm{HH}$ & $0.42 \pm 0.02$ & $0.49 \pm 0.04$ & $0.54 \pm 0.03$ & - & - \\
\hline+ & + & - & + & $\mathrm{HB}$ & $0.42 \pm 0.03$ & $0.39 \pm 0.05$ & $0.49 \pm 0.03$ & - & - \\
\hline- & - & + & - & NA & - & - & - & $0.16 \pm 0.04$ & $0.07 \pm 0.01$ \\
\hline- & - & + & + & $\mathrm{NH}$ & - & - & - & $0.23 \pm 0.04$ & $0.15 \pm 0.01$ \\
\hline- & - & - & + & NB & - & - & - & $0.22 \pm 0.04$ & $0.19 \pm 0.02$ \\
\hline+ & - & - & + & Antelope & $0.61 \pm 0.04$ & & & & \\
\hline- & + & + & - & Fielder & $0.58 \pm 0.01$ & & & & \\
\hline+ & - & - & + & NW03681 & $0.73 \pm 0.01$ & & & & \\
\hline- & - & + & - & NW07OR1066 & $0.07 \pm 0.04$ & & & & \\
\hline- & - & + & - & NW07OR1070 & $0.04 \pm 0.01$ & & & & \\
\hline- & + & - & + & OR2050272H & $0.26 \pm 0.02$ & & & & \\
\hline- & + & + & - & PI 117635 & $0.07 \pm 0.01$ & & & & \\
\hline
\end{tabular}

${ }^{\text {a }}$ AA = Ppo-A1a/Ppo-D1b AH = Ppo-A1a/Ppo-D1a/b AB = Ppo-A1a/Ppo-D1a HA = Ppo-A1ab/Ppo-D1b HH = Ppo-A1ab/Ppo-D1a/b HB = PpoA1ab/Ppo-D1a BA = Ppo-A1b/Ppo-D1b BH = Ppo-A1b/Ppo-D1a/b BB = Ppo-A1b/Ppo-D1a NA = null allele/Ppo-D1b NH = null allele/Ppo-D1a/b $\mathrm{NB}=$ null allele/Ppo-D1a

\section{Discussion}

All populations showed significant genotypic effects on kernel PPO activity. The PPO activities of lines with putative null allele at Ppo-Al in the populations derived from NW07OR1070/Antelope and NW07OR1066/OR20 $50272 \mathrm{H}$, and in the parental lines NW07OR1070 and NW07OR1066, suggest this locus contributes most to PPO activities of wild-type wheats. Of all five populations, these two had the lowest mean PPO activities. However, the average PPO activity of the NW07OR1066/OR2050272H population was significantly lower than the NW07OR1070/ Antelope population $(P<0.0001)$, although both populations segregated for the null allele on chromosome $2 \mathrm{~A}$. The NW07OR1066/OR2050272H population carried the Ppo$A l b$ (putative low PPO activity) and null alleles, while lines of the NW07OR1070/Antelope population carried either Ppo-Ala (high PPO activity) or null alleles. The lines with a null allele on chromosome $2 \mathrm{~A}$ showed significantly lower PPO activity than all other lines in both NW 07OR1070/Antelope and NW07OR1066/OR2050272H populations. Previous reports suggest null alleles also might exist at Ppo-D1. Chang et al. (2007) studied the relationship between variation in PPO genes and PPO activity of immature wheat seeds in 216 common wheat cultivars and found that TaPPO-Al and TaPPO-DI had polymorphisms related to PPO activity. Five cultivars ('Gaiyuerui', '9114', 'ZM2851', 'ZM2855', and 'Xiaobingmai33') with a null allele at $T a P P O-D 1$ were observed and showed very low PPO activity of whole grains. No PCR fragment was detected indicating that $T a P P O-D 1$ is not present in these five cultivars and provided additional evidence that null genes at PPO-encoding loci reduce enzyme activity.

The finding that Ppo-Al contributes most to PPO activity is in agreement with the results of Martin et al. (2011), who determined the effects of allelic variation for Ppo-Al and Ppo-D1 on Chinese raw noodle color profile and kernel and flour characteristics. Martin et al. (2011) found that $P p o-A 1$ had a larger effect than $P p o-D 1$ and also determined that the effects of both Ppo-Al and Ppo-D1 loci were not additive. Beecher and Skinner (2011) identified the new three genes, Ppo-A2, Ppo-B2, and Ppo-D2, in wheat. The Ppo-A2 and Ppo-D2 genes located on the long 
Table 6 Genotypes and PPO activity of all $\mathrm{F}_{3}$ populations and parents

\begin{tabular}{|c|c|c|c|c|c|c|c|c|c|}
\hline \multicolumn{2}{|l|}{$2 \mathrm{~A}$} & \multicolumn{2}{|l|}{$2 \mathrm{D}$} & \multirow[t]{2}{*}{ Genotypes $^{\mathrm{a}}$} & \multicolumn{5}{|c|}{ PPO activity (mean \pm SD) } \\
\hline $\begin{array}{l}\text { PPO18 } \\
685-b p\end{array}$ & $\begin{array}{l}\text { PPO18 } \\
876-b p\end{array}$ & $\begin{array}{l}\text { PPO29 } \\
490-b p\end{array}$ & $\begin{array}{l}\text { STS01 } \\
\text { 560-bp }\end{array}$ & & $\begin{array}{l}\text { Population } 1 \\
\text { PI 117635/Antelope }\end{array}$ & $\begin{array}{l}\text { Population } 2 \\
\text { Fielder/NW03681 }\end{array}$ & $\begin{array}{l}\text { Population } 3 \\
\text { Fielder/Antelope }\end{array}$ & $\begin{array}{l}\text { Population } 4 \\
\text { NW07OR1070/ } \\
\text { Antelope }\end{array}$ & $\begin{array}{l}\text { Population } 5 \\
\text { NW07OR1066/ } \\
\text { OR2050272H }\end{array}$ \\
\hline+ & - & + & - & $\mathrm{AA}$ & $0.57 \pm 0.05$ & $0.75 \pm 0.08$ & $0.92 \pm 0.09$ & $0.50 \pm 0.09$ & - \\
\hline+ & - & + & + & $\mathrm{AH}$ & $0.55 \pm 0.06$ & $0.64 \pm 0.08$ & $0.67 \pm 0.07$ & $0.49 \pm 0.04$ & - \\
\hline+ & - & - & + & $\mathrm{AB}$ & $0.60 \pm 0.05$ & $0.76 \pm 0.08$ & $0.76 \pm 0.06$ & $0.47 \pm 0.06$ & - \\
\hline- & + & + & - & BA & $0.10 \pm 0.01$ & $0.56 \pm 0.07$ & $0.47 \pm 0.06$ & - & $0.10 \pm 0.02$ \\
\hline- & + & + & + & $\mathrm{BH}$ & $0.16 \pm 0.02$ & $0.46 \pm 0.08$ & $0.46 \pm 0.07$ & - & $0.16 \pm 0.02$ \\
\hline- & + & + & - & $\mathrm{BB}$ & $0.21 \pm 0.02$ & $0.27 \pm 0.04$ & $0.33 \pm 0.05$ & - & $0.21 \pm 0.02$ \\
\hline+ & + & + & - & HA & $0.33 \pm 0.03$ & $0.59 \pm 0.15$ & $0.76 \pm 0.09$ & - & - \\
\hline+ & + & + & + & $\mathrm{HH}$ & $0.40 \pm 0.07$ & $0.69 \pm 0.09$ & $0.46 \pm 0.09$ & - & - \\
\hline+ & + & - & + & $\mathrm{HB}$ & $0.49 \pm 0.05$ & $0.51 \pm 0.10$ & $0.54 \pm 0.06$ & - & - \\
\hline- & - & + & - & NA & - & - & - & $0.13 \pm 0.03$ & $0.07 \pm 0.01$ \\
\hline- & - & + & + & $\mathrm{NH}$ & - & - & - & $0.12 \pm 0.02$ & $0.11 \pm 0.02$ \\
\hline- & - & - & + & NB & - & - & - & $0.18 \pm 0.06$ & $0.17 \pm 0.03$ \\
\hline+ & - & - & + & Antelope & $0.47 \pm 0.16$ & & & & \\
\hline- & + & + & - & Fielder & $0.46 \pm 0.10$ & & & & \\
\hline+ & - & - & + & NW03681 & $0.36 \pm 0.02$ & & & & \\
\hline- & - & + & - & NW07OR1066 & $0.08 \pm 0.02$ & & & & \\
\hline- & - & + & - & NW07OR1070 & $0.15 \pm 0.09$ & & & & \\
\hline- & + & - & + & OR2050272H & $0.30 \pm 0.14$ & & & & \\
\hline- & + & + & - & PI 117635 & $0.13 \pm 0.01$ & & & & \\
\hline
\end{tabular}

${ }^{\mathrm{a}}$ AA $=$ Ppo-A1a/Ppo-D1b AH = Ppo-A1a/Ppo-D1a/b AB = Ppo-A1a/Ppo-D1a HA = Ppo-A1ab/Ppo-D1b HH = Ppo-A1ab/Ppo-D1a/b HB = PpoA1ab/Ppo-D1a BA = Ppo-A1b/Ppo-D1b BH = Ppo-A1b/Ppo-D1a/b BB = Ppo-A1b/Ppo-D1a NA = null allele/Ppo-D1b NH = null allele/Ppo-D1a/b $\mathrm{NB}=$ null allele/Ppo-D1a

arms of chromosome $2 \mathrm{~A}$ and $2 \mathrm{D}$, respectively, the same chromosomes as the Ppo-Al and Ppo-Dl genes. The Ppo$B 2$ localized to chromosome 2B. Real-time PCR analysis showed that in the wheat cultivar 'Alpowa', Ppo-Ala, Ppo$A 2 b, P p o-D 1 b$, and $P p o-D 2 b$ were all expressed in developing wheat seeds, while Ppo-B2 expression was not detected. The A genome loci contributed $89.6 \%$ of the PPO gene transcripts in the developing seeds. The Ppo-Al and $P p o-A 2$ genes present together contribute far more transcript than those from either the $\mathrm{B}$ or $\mathrm{D}$ genome.

The functional PPO29 marker for the PPO gene located on chromosome 2D was developed by He et al. (2007). In their report, PPO29 marker amplified a 490-bp PCR fragment in cultivar with high PPO activity. The dominant STS marker, STS01, was developed which amplified a fragment of $560 \mathrm{bp}$ in most cultivars with low PPO activity. The STS01 marker was located on chromosome 2DL and complementary to PPO29 (Wang et al. 2008). In both Fielder/NW03681 and Fielder/Antelope populations, lines amplifying a 685-bp PCR fragment with PPO18 and a 490-bp fragment from PPO29 (AA genotype) showed higher average PPO activity in seed than lines producing a 685-bp fragment from PPO18 and a 560-bp fragment from STS01 (AB genotype). These data are in agreement with the previous data described for PPO29 and STS01. However, in the $\mathrm{F}_{3}$ of the PI 117635/Antelope population, the Ppo-Alb/Ppo-Dlb (BA) genotype was lower in activity than the Ppo-Alb/Ppo-Dla (BB) genotype. In the $\mathrm{F}_{2}$ of NW07OR1070/Antelope and in both generations of NW07OR1066/OR2050272H, the null/Ppo-Dlb (NA) genotype had the lowest average PPO activity and it was lower than null/Ppo-Dla (NB) genotype. Therefore, in the PI 117635/Antelope, NW07OR1070/Antelope, and NW07OR1066/OR2050272H populations, results opposite to those predicted from previously reported research were detected, and in some populations the PPO29 marker was associated with lower PPO activity than the STS01 marker. This conclusion was consistent with the results of our previous study in a PI 117635/IDO377s population, which also displayed results that contradicted that predicted for Ppo-D1 allele (Onto 2011). In all such cases, however, the differences observed between the genotypes were not great and occurred when Ppo-Al was fixed for either the low allele $(P p o-A 1 b)$ or the newly discovered putative null 

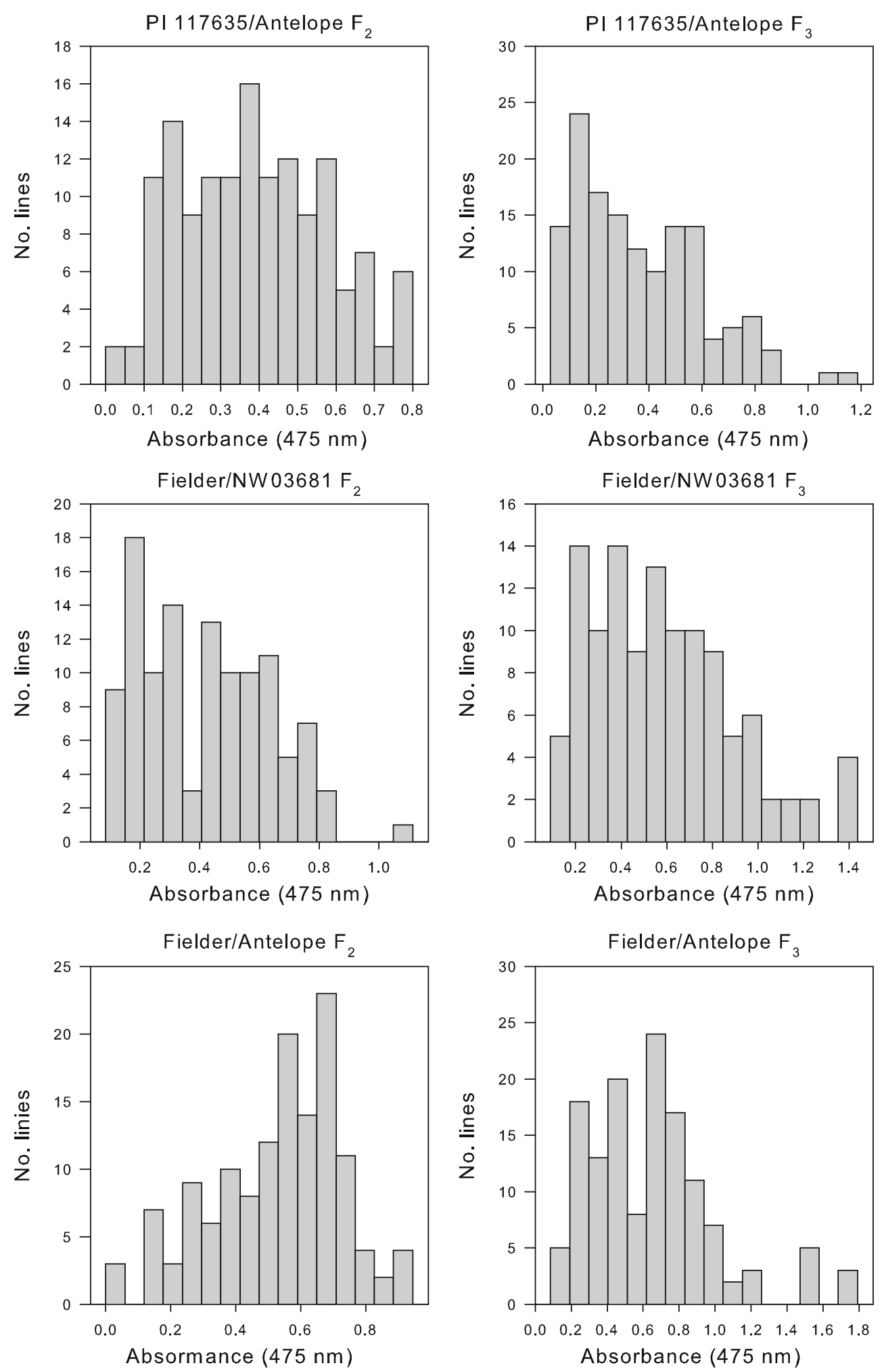

Fig. 1 Distribution of PPO activity of individual lines in the F2 and F3 generations of three populations: PI 117635/Antelope, Fielder/NW03681, and Fielder/Antelope. See Tables 5 and 6 for mean PPO values of PPO genotypes and parents

allele. Also, all of the populations with unexpected results contained in their lineages PI 117635, a low PPO line with the putative "high" PPO PCR product from PPO29. As all markers used in this study lie within the PPO loci, it is possible that a rare recombination event during the development of PI 117635 separated the site tagged by PPO29 

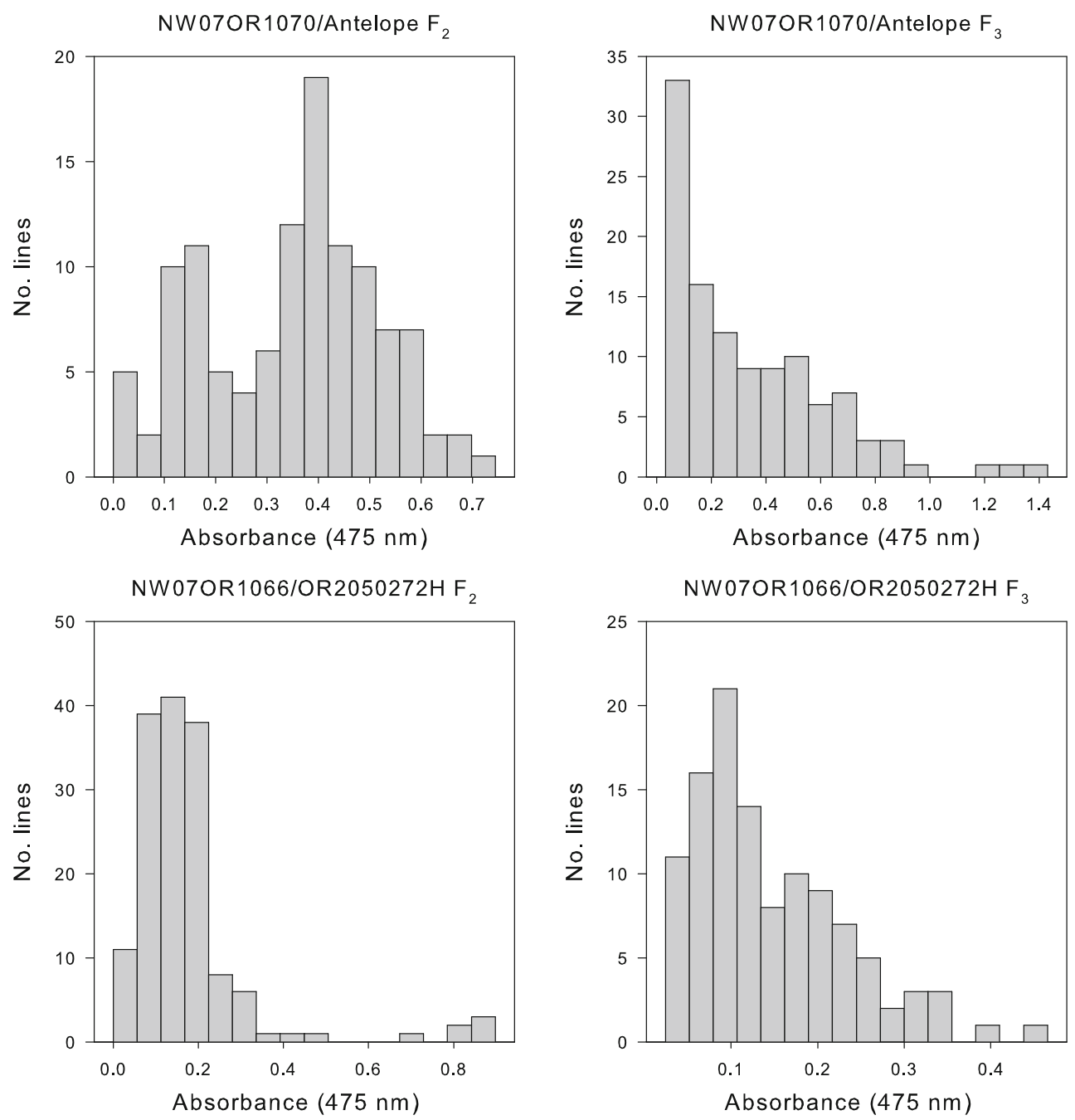

Fig. 2 Distribution of PPO activity of individual lines in the $F_{2}$ and $F_{3}$ generations of two populations: NW07OR1070/Antelope and NW07OR1066/OR2050272H. See Tables 5 and 6 for mean PPO values of PPO genotypes and parents

from sequences critical for enzyme activity. If so, future generations derived from PI 117635 could give opposite results with $\mathrm{PPO} 29$ primers.

In conclusion, wheat grown under greenhouse conditions can be used to study PPO activity. Both Ppo-Al and Ppo-DI alleles affect kernel PPO activity, but the Ppo-Al has the larger effect on PPO activity in wheats. Very low PPO activity was detected in lines with a null allele at PpoA1. The PI 117635/Antelope, NW07OR1070/Antelope, and NW07OR1066/OR2050272H populations showed the reverse phenotypic results of $\mathrm{Ppo}-\mathrm{Dl}$ marker allele from the prediction, indicating that the markers for Ppo-Dl allele give erroneous results in some genetic backgrounds. The results suggest that selection for low or null alleles only at Ppo-Al is sufficient, in some lineages, to allow development of low PPO wheat cultivars. All populations showed significant genotypic effects, whereas the generations and genotype nested within generation were not significant. This result suggests high heritability of PPO activities in early generations. Finally, low PPO lines were generated from matings of medium or high PPO parents. Breeders attempting to develop low PPO white wheats should not restrict themselves to matings involving only low PPO parents.

\section{References}

Anderson JV, Morris CF (2001) An improved whole-seed assay for screening wheat germplasm for polyphenol oxidase activity. Crop Sci 41:1697-1705

Baik B-K, Czuchajowsa Z, Pomeranz Y (1994) Comparison of polyphenol oxidase activity in wheat and flours from Australian and US cultivars. J Cereal Sci 19:291-296

Baik B-K, Czuchajowska Z, Pomeranz Y (1995) Discoloration of dough for oriental noodles. Cereal Chem 72:198-205 
Beecher B, Skinner D (2011) Molecular cloning and expression analysis of multiple polyphenol oxidase genes in developing wheat (Triticum aestivum) kernels. J Cereal Sci 53:371-378

Bernier AM, Howes NK (1994) Quantification of variation in tyrosinase activity among durum and common wheat cultivars. J Cereal Sci 19:157-159

Chang C, Zhang H-P, Xu J, You M-S, Li B-Y, Liu G-T (2007) Variation in two PPO genes associated with polyphenol oxidase activity in seeds of common wheat. Euphytica 154:181-193

Demeke T, Morris CF (2002) Molecular characterization of wheat polyphenol oxidase (PPO). Theor Appl Genet 104:813-818

Demeke T, Morris CF, Campbell KG, King GE, Anderson JA, Chang HG (2001) Wheat polyphenol oxidase distribution and genetic mapping in three inbred line populations. Crop Sci 41:1750-1757

Doyle JJ, Doyle JL (1987) A rapid DNA isolation procedure for small quantities of fresh leaf tissue. Phytochem Bull 19:11-15

Feillet P, Autran JC, Icard-Verniere C (2000) Pasta brownness: an assessment. J Cereal Sci 32:215-233

Flurkey WH (1989) Polypeptide composition and aminoterminal sequence of broad bean polyphenol oxidase. Plant Physiol 91:481-483

He XY, He ZH, Zhang LP, Sun DJ, Morris CF, Fuerst EP, Xia XC (2007) Allelic variation of polyphenol oxidase (PPO) genes located on chromosome $2 \mathrm{~A}$ and $2 \mathrm{D}$ and development of functional markers for the PPO genes in common wheat. Theor Appl Genet 115:47-58

Jimenez M, Dubcovsky J (1999) Chromosome location of genes affecting polyphenol oxidase activity in seeds of common and durum wheat. Plant Breed 118:395-398

Jukanti AK, Bruckner PL, Fischer AM (2004) Evaluation of wheat polyphenol oxidase genes. Cereal Chem 81:481-485

Kruger JE, Hatcher DW, DePauw R (1994) A whole seed assay for polyphenol oxidase in Canadian prairie spring wheats and its usefulness as a measure of noodle darkening. Cereal Chem 71:324-326

Lee CY, Whitaker JR (1995) Enzymatic browning and its prevention ACS Syms Ser 600. American Chemical Soc, Washington, DC

Li WL, Faris JD, Chittoor JM, Leach JE, Hulbert SH, Liu DJ, Chen PD, Gill BS (1999) Genomic mapping of defence response genes in wheat. Theor Appl Genet 98:226-233

Mares DJ, Campbell AW (2001) Mapping components of flour and noodle colour in Australian wheat. Aust J Agric Res 52:1297-1309

Marsh DR, Galliard T (1986) Measurements of polyphenol oxidase activity in wheat-milling fractions. J Cereal Sci 4:241-248
Martin JM, Berg JE, Hofer P, Kephart KD, Nash D, Bruckner PL (2011) Allelic variation of polyphenol oxidase genes impacts on Chinese raw noodle color. J Cereal Sci. doi:10.1016/j.jcs. 2011.08.003

Mayer AM, Harel E (1979) Polyphenol oxidases in plants. Phytochemistry 18:193-215

McCaig TN, Fenn DYK, Knox RE, DePauw RM, Clarke JM, McLeod JG (1999) Measuring polyphenol oxidase activity in a wheat breeding program. Can J Plant Sci 79:507-514

Milner M, Gould MR (1951) The quantitative determination of phenol oxidase activity in wheat varieties. Cereal Chem $28: 473-478$

Onto S (2011) Genetics of polyphenol oxidase (PPO) activity in wheat (Triticum aestivum L.). Theses, Dissertations, and Student Research in Agronomy and Horticulture. Paper 35. http:// digitalcommons.unl.edu/agronhortdiss/35

Park WJ, Shelton DR, Peterson CJ, Martin TJ, Kachman SD, Wehling RL (1997) Variation in polyphenol oxidase activity and quality characteristics among hard white wheat and hard red winter wheat samples. Cereal Chem 74:7-11

Raman R, Raman H, Johnstone K, Lisle C, Smith A, Martin P, Allen $\mathrm{H}$ (2005) Genetic and in silico comparative mapping of the polyphenol oxidase gene in bread wheat. Funct Intergr Genomics 5:185-200

Robb DA (1984) Copper protein and copper enzyme, vol 2. In: Lontie R (ed) CRC Press, Boca Raton, FL, pp 207-241

Singh R, Sheoran IS (1972) Enzymatic browning of whole wheat meal flour. J Sci Food Agric 23:121-125

Steffens JC, Harel E, Hunt MD (1994) Polyphenol oxidase. In: Ellis BE, Kuroki GW, Stafford HA (eds) Genetic engineering of plant secondary metabolism. Plenum Press, New York, pp 275-313

Sun DJ, He ZH, Xia XC, Zhang LP, Morris CF, Appels R, Ma WJ, Wang H (2005) A novel STS marker for polyphenol oxidase activity in bread wheat. Mol Breed 16:209-218

Udall J (1996) Important alleles for noodle quality in winter wheat as identified by molecular markers. MS Thesis, University of Idaho, Moscow, ID

Wang XB, Ma CX, He KQ, Si HQ, Zhang YL (2008) Development and application of a STS marker for grain PPO gene located on chromosome 2D in common wheat. Scientia Agric Sin 39(6): 1583-1590

Wrigley CW (1976) Single seed identification of wheat varieties: use of grain hardness testing, electrophoretic analysis and a rapid test paper for phenol reaction. J Sci Food Agric 27:429-432 